\title{
Web-based public complaints information system for Subang City
}

\author{
Emy Lenora Tatuhey ${ }^{1}$ \\ Study Program, \\ Information System \\ ,STIMIK \\ Sepuluh Nopember \\ Jayapura \\ emytatuhey@gmail.com
}

\author{
Tukino $^{2}$ \\ Study Program, \\ Information System \\ Faculty of Computer Science, \\ Universitas Buana Perjuangan \\ Karawang, Indonesia \\ tukino@ubpkarawang.ac.id
}

\author{
Irpan Hilmi ${ }^{3}$ \\ Study Program, \\ Information System \\ Faculty of Computer Science, \\ Universitas Buana Perjuangan \\ Karawang, Indonesia \\ irpanhilmi@ubpkarawang.ac.id
}

\begin{abstract}
Abstra -Keluhan masyarakat pada saat ini terbatas oleh media sebagian masyarakat merasa sulitnya untuk menyampaikan atau melaporkan peristiwa yang terjadi diwilayah tersebut. Pengaduan keluhanpun masih sepenuhnya belum menggunakan media teknologi informasi hal ini membuat masyarakat sulit untuk memberikan saran atau menyampaikan keluhannya. Dari permasalahan tersebut penulis mengembangkan sistem informasi untuk proses pengaduan masyarakat dengan metode waterfall. Tujuan dibuatkannya sistem ini yaitu untuk membuat website desa jatibaru, membuat website pengaduan bagi masyarakat, sehingga keluhan yang ada dimasyarakat bisa tersampaikan dengan baik melalui website pengaduan, masyarakat dapat melihat kembali pengaduan untuk mengetahui apakah pengaduan sudah diproses atau belum. Pengembangan sistem menggunakan bahasa pemograman PHP dan HTML. Hasil akhir dari penelitian ini menghasilkan sebuah sistem informasi pengaduan masyarakat supaya aspirasi dari masyarakat tersampaikan dengan baik untuk pemerintah desa, semua pengaduan akan dibahas oleh aparatur desa untuk meminimalisir pengaduan dari masyarakat dan dengan adanya sistem ini juga dapat membantu memonitoring pengaduan yang disampaikan masyarakat.
\end{abstract}

Kata Kunci : Pengaduan Masyarakat, Keluhan, Sistem Informasi

Abstract-The media currently limit public complaints, and some people find it difficult to convey or report events in the area. Complaints are still not fully using information technology media. This makes it difficult for the public to provide suggestions or submit complaints. The authors developed an information system for the public complaint process using the waterfall method from these problems. This system aims to create a Jatibaru village website and create a complaint website for the community so that complaints in the community can be conveyed properly through the complaints website. The public can review the complaints to determine whether the complaints have been processed or not. System development using the PHP and HTML programming languages. The final result of this study resulted in a public complaint information system so that the aspirations of the community were properly conveyed to the village government, all complaints would be discussed by the village apparatus to minimize complaints from the community, and with this system, it can also help monitor complaints submitted by the community.

Keywords: Public Complaints, Complaints, Information Systems

\section{INTRODUCTION}

A government is expected to have service media that can be accessed via the internet to accommodate input from the community. The author proposes to make a Web-Based Jatibaru Village Community Complaint service. Make it easier for the community to give or complain suggestions and criticisms about the problems in Jatibaru Village because these problems can become obstacles to the progress of a village. All residents of Jatibaru Village can access the complaint system to provide suggestions and criticisms for the village government to be more advanced and better in the future; aspirations in the form of suggestions and criticisms are a form of attention from the community to the village government.

If the community wants to convey their aspirations, they can open the Jatibaru Village website and enter the username and password that the community already has. After entering the system, there will be several menus, one of which is a menu for complaints or aspirations from the community to the village. The community needs to fill out the complaint form. And can submit more than one complaint. The submitted complaint form will be stored and recapitulated by the village. Every week the village holds weekly meetings, which are held on Wednesdays, to discuss complaints submitted by the community to minimize negative things that arise in the community. The village head also evaluates the RT or Kadus who are less active in attending weekly meetings held at the Jatibaru Village Hall. 


\section{METHOD}

\section{A. Data Collection Techniques}

In this process, in-depth research is carried out on the data needed during the process of making the system to be designed. Following are the stages of data collection.

a) Literature Study

Looking for theoretical references related to the research topic raised, theories obtained from several literature sources. There are several sources of literature that are often used in the form of books, journals, theses.

b) Observation

The purpose of the observation is to observe the research site in order to get the information needed by the researcher, by going directly to the object being studied, namely the Jatibaru Village Office, Ciasem Subang.

c) Interview

In this interview, conducting a dialogue by asking questions to the village apparatus and the Jatibaru village community aims to find out the process of submitting complaints so that it becomes material for building a new system.

\section{B. System Development Method}

The waterfall method is a method commonly referred to as the classic life cycle, describing a systematic approach to sequential software development. [9] The following are the stages of the waterfall model:

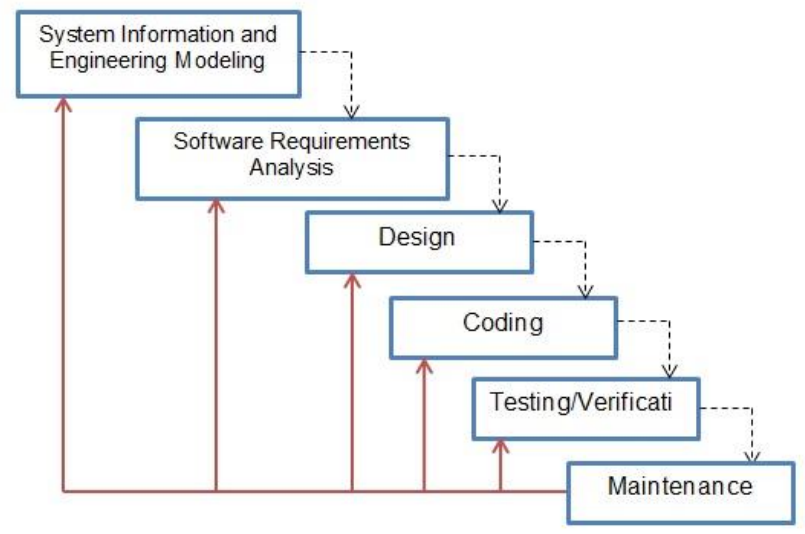

Figure 1 Iterative waterfall[12]

1. System Information and Engineering Modeling

This stage starts from gathering requirements to be applied to the device system that will be developed.

2. Software Requirements Analysis

This stage is to collect the required needs with incentives to be understood by users, these needs are intended for users as system users later.
3. Design

This stage does the design of the interface design requirements for the system to be developed, the interface design needs to be done when you want to do system development.

4. Coding

The stages of making this program must be implemented using software.

5. Testing

This stage of system testing is carried out logically and functionally which is used to determine the parts of the system that have been previously tested. This testing is to minimize errors that occur in the program.

\section{Maintenance}

The maintenance stage or system maintenance needs to be done because the system needs can continue to be improved after use.

\section{RESULTS AND DISCUSSION}

In this study, the collection of survey requirements aims to analyze existing problems in village government and evaluate the standard application process. In this case, it is a systematic analysis. Present and find solutions to village and community leaders' problems and needs to find out user desires for applications used with the waterfall method as system development. Here are the steps:

\section{A. Current System Analysis}

At the Jatibaru Village agency currently, it is still done manually or by greeting with the village apparatus, not a few people want to express opinions and input for the Jatibaru Village government to be better, some problems or obstacles that occur, namely regarding the process of submitting complaints, they still often experience problems. impasse, such as the village head and village apparatus, which are often difficult to find, the community is reluctant to have direct dialogue when conveying their aspirations to the village apparatus, and also both village officials and the community are often constrained by time when they want to go to the village office in carrying out discussions, both residents who want to express their aspirations as well as village officials who want to respond to all community complaints.

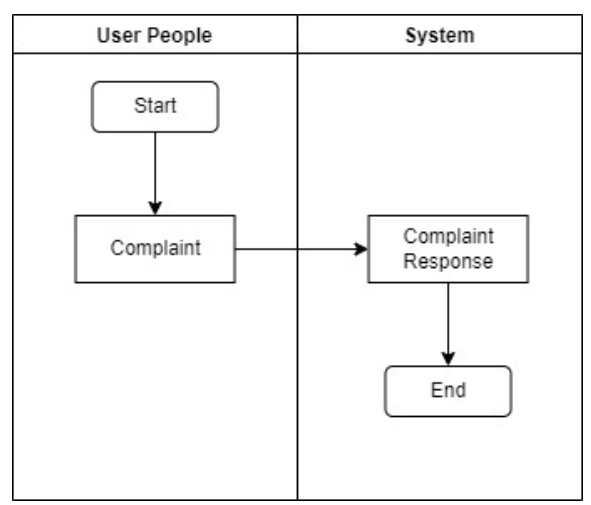

Figure 2 Running System 


\section{B. System Design}

After knowing the description that has been running and the analysis results to determine user satisfaction regarding the system developed at the Jatibaru Village Office, Ciasem Subang next is the development and design of the system. The following are the stages in making the system:

\section{System Proposed}

The proposed system aims to identify and evaluate problems found during research. The proposed system consists of analyzing problems and analyzing needs. Therefore, the author gives the Jatibaru Village agency an idea to handle the above problems. Below is the proposed system procedure for Jatibaru Village, Ciasem Subang.

After analyzing the current system in Jatibaru Village, a system is proposed that will provide online complaint services.

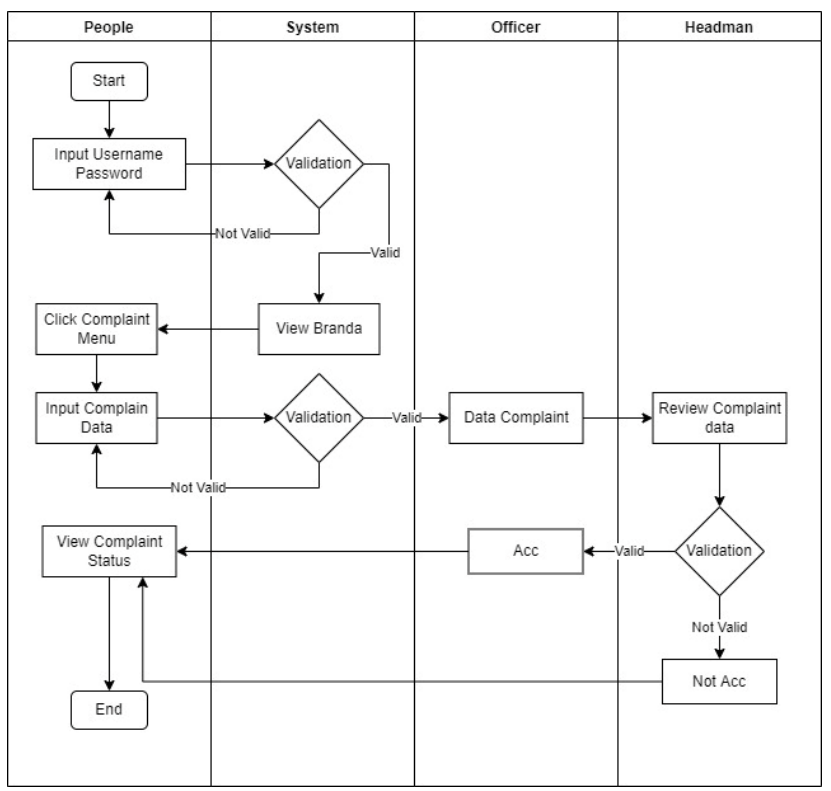

Figure 3 System Flowchart

In the flow above, it can be seen that the community will start the complaint service by opening the website that has been built. Then the community can enter their username and password to be able to log in to the home page then choose the complaint form and fill out the complaint, after that the admin receives the complaint and the village head discusses to provide a reply to the complaint submitted by the community. The village head confirms to the admin to reply to the complaint, then the officer in charge of the complaint can upload the progress of the settlement that is being carried out, after the complaint is processed the community can view the complaint again [10].

\section{Use Case Diagram}

Use case diagrams are diagrams that describe the scenario of the system that will be created and explain between the actors and the activities that will be carried out on the system that has been built.

The use case diagram below describes the overall activities carried out by each user.

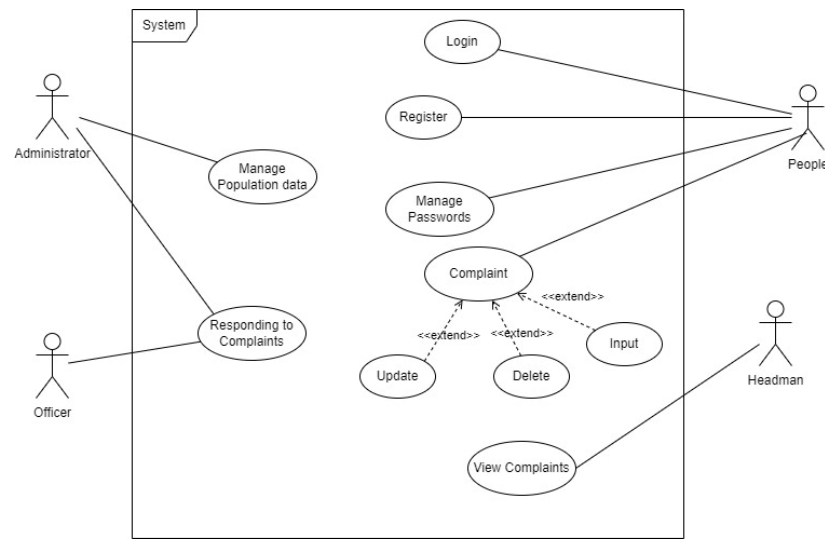

Figure 4 Usecase Diagram

\section{Activity Diagram}

This activity diagram illustrates what the public does in making complaints. By logging in first, then if the data validation is correct, the system will display the user's main page. Next, the user will select the complaint menu, the system displays the complaint form, then the user fills out the complaint if the complaint form has been filled in, the system will return to the main page and the complaint data is stored in the database. Users can also add complaints if they want to make more than one complaint.

\section{Sequence Diagram}

In this complaint input sequence diagram, it describes the lifeline between objects when the user inputs a complaint. Below is the sequence diagram for the complaint input:

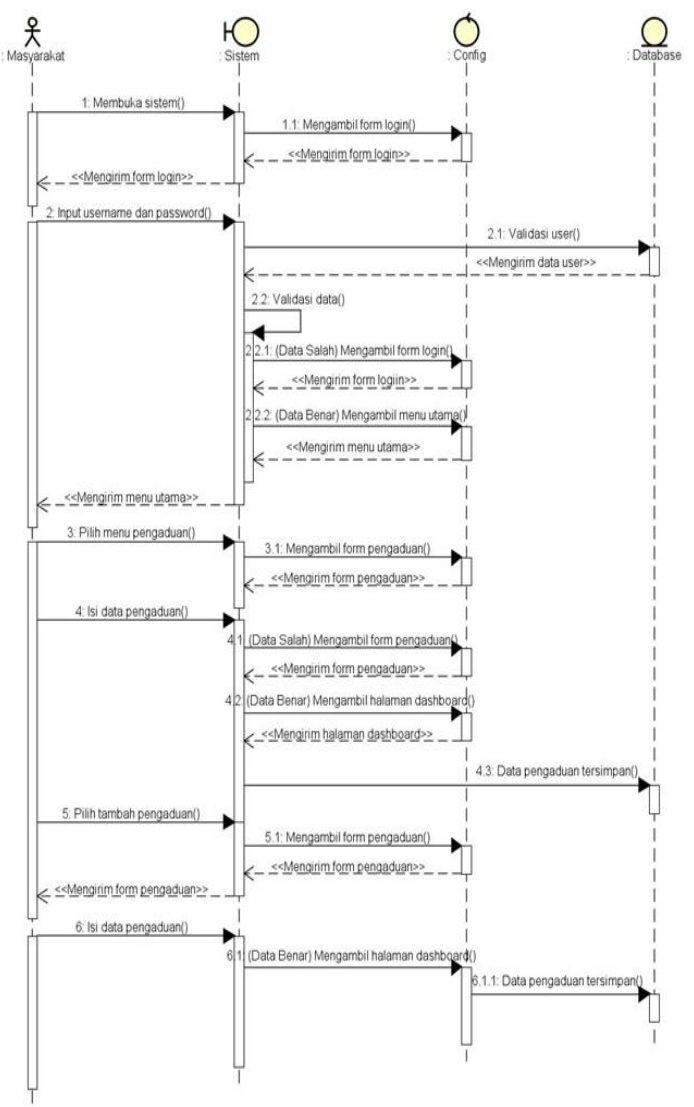

Figure 6. Sequence diagram of complaint input 


\section{Class Diagram}

Class Diagram is a diagram that describes the form of the system in the process of class definition on the system to be built.

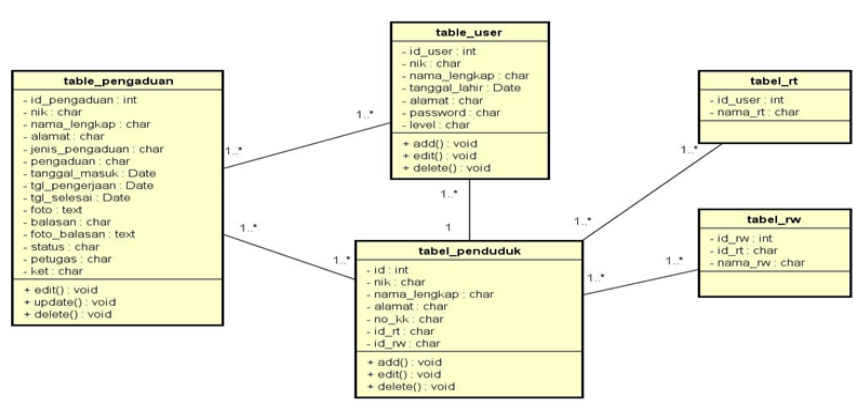

Figure 7. Class Diagram

\section{System Implementation}

In the implementation of this interface, it displays a system display that has been created and run using Google Chrome and Xampp as the web server. Here is the interface implementation view:

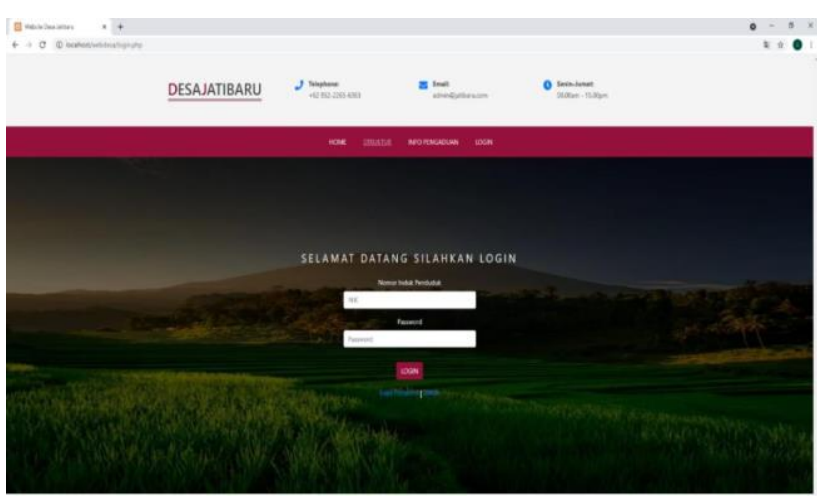

Figure 8. Login page

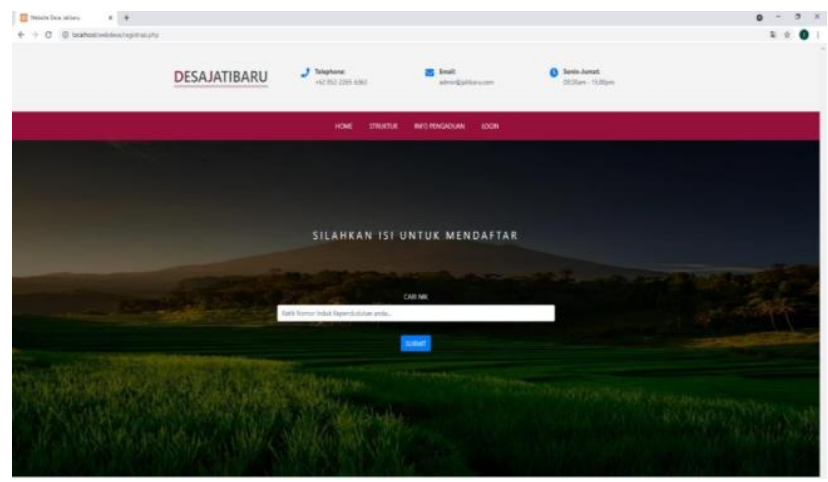

Figure 9. Registration Page

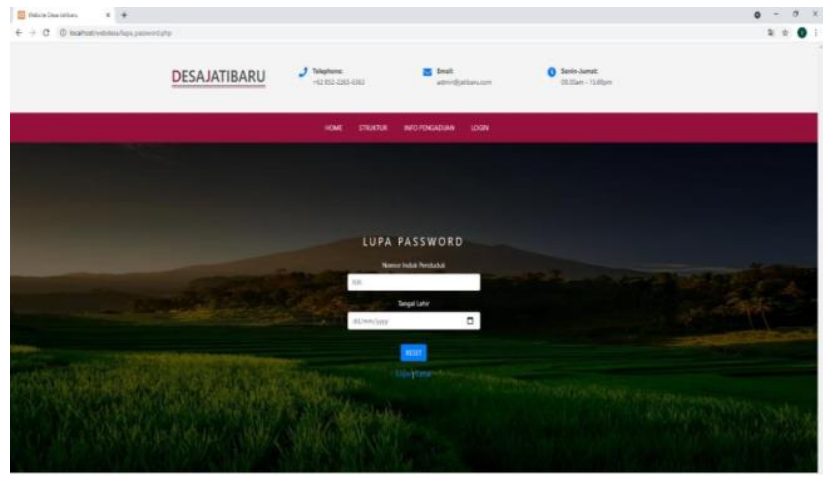

Figure 10. Forgot Password Page
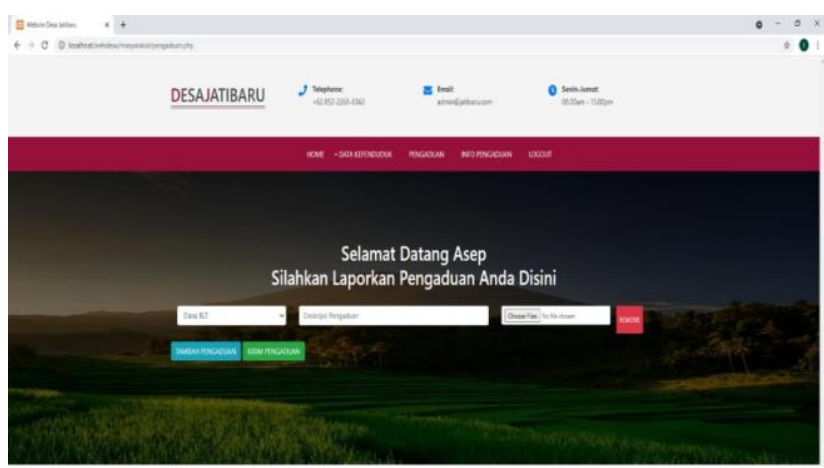

Figure 11. Complaint Input Page

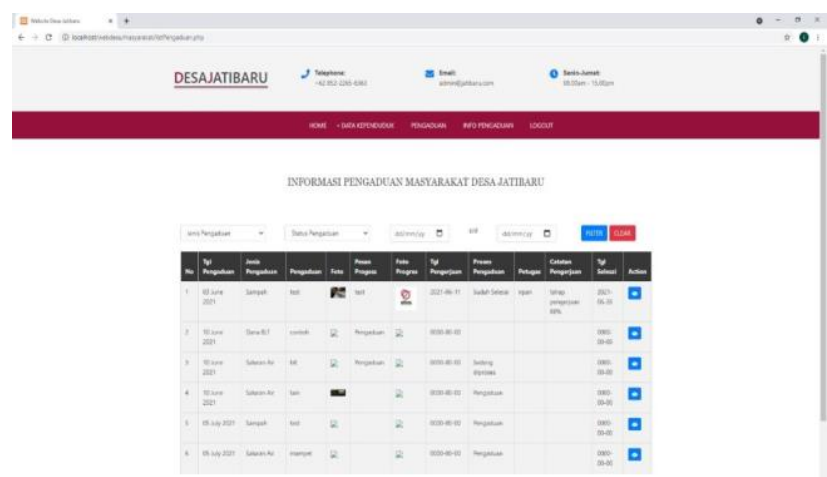

Figure 12. Complaint Review Page

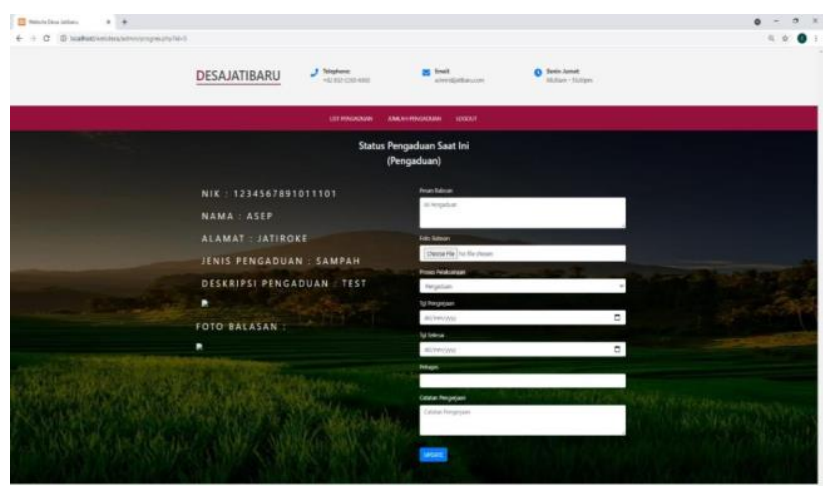

Figure 13. Complaint Responding Page

\section{System Evaluation}

This web-based public complaint information system aims to create a website where people can communicate their wishes to village officials, the wishes that exist in the community are solely for the progress of the village itself both in the field of development, facilities and infrastructure 
in Jatibaru village, every user who participating are granted access with privileges granted by the system, therefore every connection with the system already has a limit for each user.

The results of testing the system using the black box testing method to determine its functionality so that it can be concluded that the resulting system functions as expected. The system that was built also helps the village head and village parties to know what is being communicated by the community.

\section{CONCLUSION}

Based on the research results in making the final project on a web-based public complaint information system at the Jatibaru Ciasem Subang village office, the researchers got several conclusions, namely as follows:

1. With the creation of a web-based public complaint system, the complaint process can be carried out easily and relevantly for the Jatibaru village community. This system also has a complaint info feature to make it easier for the public to see the progress of the complaints submitted.

2. Complaints submitted will be discussed by village officials and village heads so that they can be used as evaluation material for village officials to be even better.

\section{REFERENCE}

[1] D. Haryanto and A. Nasihin, "Sistem Informasi Kearsipan Surat Masuk Surat Keluar di STIKes Mitra Kencana Kota Tasikmalaya," J. Tek. Inform., vol. 6, no. 2, pp. 22-30, 2018, [Online]. Available: http://jurnal.stmik-dci.ac.id/index.php/jutekin/.

[2] B. Huda, "Sistem Informasi Data Penduduk Berbasis Android Dan Web Monitoring Studi Kasus Pemerintah Kota Karawang (Penelitian dilakukan di Kab. Karawang)," Buana Ilmu, vol. 3, no. 1, pp. 62-69, 2018, doi: 10.36805/bi.v3i1.456.

[3] S. W. Mursalim, "Analisis Manajemen Pengaduan Sistem Layanan Sistem Aspirasi Pengaduan Online
Rakyat (LAPOR) di Kota Bandung," J. Ilmu Adm. Media Pengemb. Ilmu dan Prakt. Adm., vol. 15, no. 1, pp. 1-17, 2018, doi: 10.31113/jia.v15i1.128.

[4] A. S. Cahyono, "Pengaruh media sosial terhadap perubahan sosial masyarakat di Indonesia," J. ilmu Sos. ilmu Polit. diterbitkan oleh Fak. Ilmu Sos. Polit. Univ. Tulungagung, vol. 9, no. 1, pp. 140-157, 2016, [Online].Available:http://www.jurnalunita.org/index.p hp/publiciana/article/download/79/73.

[5] E. Widyawati, "Rancang Bangun Aplikasi Kependudukan Berbasis Web Di Desa Kedungrejo Waru-Sidoarjo," J. Manaj. Inform., vol. 6, no. 1, 2016.

[6] S. Anton, I. C. Alex, and N. Kristiawan;" "Sistem Penilaian Kinerja Pegawai dalam Pelayanan Nasabah pada ... (Sujarwo dkk.)," Penilaian, Sist. Pegawai, Kinerja Nasabah, Pelayanan Kinerja, Abstr. Lang. Unified Model., pp. 270-275, 2019, [Online]. Available:

http://undhari.ac.id/jurnal/index.php/simtika/article/vie w/15.

[7] C. Surya and S. Sara, "Jaringan Sistem Informasi Robotik Vol. 2, No. 02, September 2018," Jar. Sist. Inf. Robot., vol. 2, no. 02, pp. 115-129, 2018.

[8] D. Utama, A. Johar, and F. F. Coastera, "Minuman Restaurant Berbasis Client Server Dengan P Latform Android," pp. 288-300, 2016.

[9] A. Galih Pradana and S. Nita, "Rancang Bangun Game Edukasi " AMUDRA' Alat Musik Daerah Berbasis Android Afista Galih Pradana Sekreningsih Nita," Semin. Nas. Teknol. Inf. dan Komun., vol. 2, no. 1, pp. 77-80, 2019.

[10] D. Kurniawan, A. L. Hananto, and B. Priyatna, "Modification Application of Key Metrics 13x13 Cryptographic Algorithm Playfair Cipher and Combination with Linear Feedback Shift Register (LFSR) on Data Security Based on Mobile Android," Int. J. Comput. Tech.--, vol. 5, no. 1, pp. 65-70, 2018. 